\title{
Hepatitis B Virus Core Antibody Positive
}

National Cancer Institute

\section{Source}

National Cancer Institute. Hepatitis B Virus Core Antibody Positive. NCI Thesaurus. Code C148282.

An indication that antibodies that recognize a hepatitis B virus core protein have been detected in a sample. 